\title{
Yoctomole per Liter
}

National Cancer Institute

\section{Source}

National Cancer Institute. Yoctomole per Liter. NCI Thesaurus. Code C68890.

A unit of concentration (molarity unit) equal to one septillionth of a mole (10E-24 mole)

of solute in one liter of solution. 